\title{
ANTIMICROBIAL RESISTANCE AND BIOLOGICAL PROPERTIES OF STAPHYLOCOCCUS SPP. ISOLATED FROM PIGS
}

\author{
Yuriy VISHOVAN, Valerii USHKALOV, Oleksandra KEPPLE, Andry GRANATE \\ Ukrainian Laboratory of Quality and Safety of Agricultural Products, \\ National University of Life and Environmental Sciences of Ukraine
}

Corresponding author: Yuriy Vishovan, e-mail: anatomi1991@gmail.com

Key words: Staphylococcus spp., plasma coagulation, biological properties, antibiotics, susceptibility, resistance.
Cuvinte cheie: Staphylococcus spp., coagularea plasmei, proprietăți biologice, antibiotice, sensibilitate, rezistenţă.
Introduction. Representatives of the genus Staphylococcus spp. cause a significant proportion of diseases in animals and humans. Nowadays the problem of their acquired antibiotic resistance is an urgent concern.

Material and methods. Isolation and identification of Staphylococcus spp. carried out in accordance with DSTU EN 6888:2003 standard. The susceptibility of the strains to antibiotics was determined by the disk diffusion method. Interpretation of the results was carried out in accordance with the recommendations of the 8th version of EUCAST. Results. 77 strains of Staphylococcus spp. Collected from sows at the farm No. 2, were isolated: hemolytic properties were detected in 90.6\% (39 coagulases positive and 19 coagulase negative); 22 (56.4\%) strains of coagulase-negative Staphylococcus spp.; $13.6 \%$ of isolates had hemolytic properties. The results of antibiograms of crops from the farm No.1: $51.8 \%$ of strains were susceptibile to penicillin, 47.6\% - resistant; 13.62 - susceptibile to fluoroquinolones, $80.9 \%$ - resistant; $96.7 \%$ - susceptibile to chloramphenicol, no resistant strains were detected.

Conclusions. Acquired resistance of Staphylococcus spp. to certain groups of antibiotics isolated from pigs, indicated the irrational use of antimicrobial therapy. Differences were found in the susceptibility of coagulase-positive and coagulase-negative Staphylococcus spp. to all groups of antibiotics.

\section{REZISTENŢA LA ANTIMICROBIENE ŞI PROPRIETĂȚILE BIOLOGICE A STAPHYLO- COCCUS SPP. IZOLATE DE LA PORCINE}

Introducere. Reprezentanții genului Staphylococcus provoacă un număr semnificativ de boli la animale și la oameni. Actualmente, o problemă majoră o prezintă rezistența dobândită a acestor tulpini la antibiotice.

Material și metode. Izolarea și identificarea Staphylococcus spp. s-a realizat în conformitate cu standardul DSTU EN 6888:2003. Sensibilitatea tulpinilor la antibiotice a fost determinată prin metoda disc-difuzimetrică, iar interpretarea rezultatelor a fost efectuată potrivit recomandărilor EUCAST, versiunea 8.

Rezultate. De la scroafele din ferma $\mathrm{nr} .1$ au fost izolate 77 de tulpini de Staphylococcus spp: proprietăți hemolitice au fost detectate la 90,6\% din probe (39 coagulazo-pozitive și 19 coagulazo-negative). De la scroafele din ferma nr.2 au fost izolate 22 $(56,4 \%)$ tulpini de Staphylococcus spp. coagulozo-negative, dintre care 13,6\% posedau proprietăți hemolitice. Rezultatele antibioticogramei culturilor de la ferma nr.1 ne arată că 51,8\% din culturi sunt sensibile și 47,6\% sunt rezistente la peniciline; 13,6\% sunt sensibile și 80,9\% sunt rezistente la fluorochinolone, iar 96,7\% din tulpini au fost sensibile la cloramfenicol, nefiind detectate culturi rezistente.

Concluzii. Rezistența dobândită la tulpinile de Staphylococcus spp, izolate de la porcinele din ferma nr.1, față de anumite grupuri de antibiotice, indică utilizarea irațională a terapiei antimicrobiene. Astfel, s-au constatat diferențe în sensibilitatea tulpinilor de Staphylococcus spp, coagulazo-pozitive și coagulazo-negative, la toate grupele de antibiotice. 


\section{INTRODUCTION}

Staphylococcus carriers were an important source of contamination for food, raw materials, birds, pigs and pork products $(1,2)$. It has been repeatedly proven that pigs were sources of staphylococci, in particular methicillin-resistant $S$. aureus (MRSA) (3). Such cases were especially common in Denmark (4), Canada (4), Germany (6) and Switzerland (7). In young pigs, the disease manifests itself in the form of exudative epidermitis (EE), caused by strains of Staphylococcus hyicus, Staphylococcus aureus and Staphylococcus chromogenes, which produce exfoliative toxins. However, pigs in most cases were hidden carriers (7). Experimental transfer of methicillin-resistant $S$. aureus to minks during feeding of pork waste contaminated with MRSA is also known (9). In 2017, 80 methicillin-resistant staphylococcus strains were isolated in Ukraine, including $77.5 \%$ from domestic animals, $11.3 \%$ from poultry, $6.3 \%$ from cattle and $5 \%$ from pigs (10).

The purpose of the study was to investigate the biological properties and antibiotic resistance of Staphylococcus spp. isolated from pigs of two industrial pig farms located in Kyiv (No.1) and Vinnytsa regions (No.2).

\section{MATERIAL AND METHODS}

Isolation and identification of Staphylococcus spp. was conducted in accordance with: DSTU EN 6888:2003 "Microbiology of food and animal feed" standard was cultivated to the Baird Parker agar (Merck) medium and were incubated at $37^{\circ} \mathrm{C}$ for 24-48 hours. Isolates produced on Baird Parker agar at the end of this period were defined by morphology colony, Gram stain, catalase test, and coagulation test. The hemolytic properties of staphylococci were studied on Columbia blood agar (BioMerieux). Selected colonies from Columbia blood agar introduced into Tryptone-soy broth and cultured at $\mathrm{t} 35^{\circ} \mathrm{C}$ for $2-4$ hours. The optical density was determined using a densitometer DEN-1(Biosan) and McFarland standard (HiMedia). The susceptibility of strains to antibiotics was determined by disc-diffusion method using Müller-Hinton agar, inoculum: 0.5 according to the McFarland turbidity standard and were incubated at $35^{\circ} \mathrm{C}$, for $18 \pm 2$ hours. The results were assessed in accordance with the re-commendations of version 8 of the European Committee on Antimicrobial Susceptibility Testing EUCAST (11) and Guidelines "Determination of susceptibility of microorganisms to antibacterial drugs" (12).

\section{RESULTS}

Farm No. 1 proved to be a satisfactory farm in terms of safety against contagious diseases; number of pigs was up to 2500 heads. There were 210 pigs. Purulent diseases, abscesses and boils were not reported in piglets. Of the 77 sows sampled from the nose Staphylococcus spp. were isolated in 64 cases (83.1\%). All strains grown on the Beard Parker agar had typical colonies of black and grey, shiny and convex with a diameter of $1 \mathrm{~mm}$ to 1.5 $\mathrm{mm}$ after incubation for 24 hours and a diameter of $1.5-2.5 \mathrm{~mm}$ after 48 hours of incubation. The 39 isolates (60.94\%) were coa-gulated with rabbit plasma. The ability to hemo-lysis of sheep erythrocytes showed only $58(90.6 \%)$ of strains. Of these, 39 coagulase-positive strains and 19 coagulase-negative strains did not show hemolytic properties of 6 coagulase-negative strains.

The farm No. 2 proved to be a satisfactory farm in terms of contagious diseases; number of pigs was up to 3500 heads. Diseases caused by Sta-phylococcus spp. we're not registered. In 22 samples (56.4\%), isolates of Staphylococcus spp. were isolated from 39 sows from farm No.2.

The isolates grew in the form of shiny black and grey colonies with a narrow white margin. The isolates did not coagulate plasma. The 3 strains $(13.6 \%)$ from the isolated strains had hemolytic properties.

Staphylococcus had a natural susceptibility to penicillins, but subsequently acquired resistance to them (13). In the study, were used: Natural Penicillin, Benzylpenicillin; Semisynthetic Oxacillin, Gentamicin, Tobramycin from the aminoglycosides group, and Erythromycin from the macrolids group (13). The susceptibility to natural Tetracycline and Semisynthetic Doxycycline; Lincomycin and Clindamycin from the group of lincosamides was investigated. Susceptibility for norfloxacin was recommended for screening susceptibility for all fluoroquinolones (11). There were studied Norfloxacin, Ciprofloxacin, Ofloxacin, Pefloxacin, Lomefloxacin, Levofloxacin, Sparfloxacin and Gatifloxacin $(12,13)$. Susceptibility to Chloramphenicol, and Rifampicin was investigated (11).

$51.87 \%$ of the selected strains obtained at the farm No.1 were susceptible to Penicillin antibiotics, 
and $47.59 \%$ were resistant. $78.48 \%$ of bacterial strains showed susceptibility to aminoglycosides, and $21.52 \%$ of the strains were resistant. $87.1 \%$ of strains showed susceptibility to macrolides. $70.45 \%$ of the isolates were susceptible to tetracyclines. $70 \%$ of isolates showed susceptibility, and $30 \%$ were resistant to lincosamides. $13.62 \%$ were susceptible, and $80.93 \%$ - resistant to fluoroquinolones. $96.72 \%$ of revealed strains were susceptible to chloramphenicol. $73.53 \%$ of the studied isolates were susceptible to rifampicin.
10 strains from 22 pigs, on farm No. 2, were isolated and an antibiogram was determined (tab. 1). It was established that 10 isolated strains were resistant to oxacillin and clindamycin. 3 strains were susceptible, and 7 - resistant to benzylpenicillin and norfloxacin. 1 culture was susceptible, and 9 - resistant to tetracycline and erythromycin. 4 strains were susceptible, and 6 - resistant to chloramphenicol.

Table 1. Ranges of growth inhibition diameters of the studied cultures isolated from pigs on farm No. 2, mm. MinMax.

\begin{tabular}{lcccc}
\hline Name of antibiotic & $\begin{array}{c}\text { Eucast interpretation (version 8.0) } \\
\text { and Guidelines “Determination } \\
\text { of susceptibility of microorganisms } \\
\text { to antibacterial drugs" }\end{array}$ & $\begin{array}{c}\text { Ranges of diameters } \\
\text { of cultures growth } \\
\text { inhibition mm. } \\
\text { Min-Max }\end{array}$ & $\begin{array}{c}\text { S strains } \\
\text { (n) }\end{array}$ & $\begin{array}{c}\text { R strains } \\
\text { (n) }\end{array}$ \\
\hline Benzylpenicillin & $26>\mathrm{s} ; 26<\mathrm{r}$ & $0-29$ & 3 & 7 \\
\hline Oxacillin & $18 \geq \mathrm{s} ; 17<\mathrm{r}$ & $0-16$ & 0 & 10 \\
\hline Erythromycin & $21>\mathrm{s} ; 18<\mathrm{r}$ & $16-25$ & 1 & 9 \\
\hline Clindamycin & $22>\mathrm{s} ; 19<\mathrm{r}$ & $0-17$ & 0 & 10 \\
\hline Norfloxacin & $24>\mathrm{s} ; 24<\mathrm{r}$ & $0-28$ & 3 & 7 \\
\hline Tetracycline & $22>\mathrm{s} ; 19<\mathrm{r}$ & $17-24$ & 1 & 9 \\
\hline Chloramphenicol & $18>\mathrm{s} ; 18<\mathrm{r}$ & $15-22$ & 4 & 6 \\
\hline
\end{tabular}

Note: "0" - continuous growth, "15-22" - the minimum and maximum value of growth inhibition of the test culture

Number of coagulase-positive and coagulase-negative strains isolated from the farm No. 1 was showed in Table 2.

There was $100 \%$ resistance to benzylpenicillin among 18 coagulase-positive strains of Staphylococcus spp. from isolated strains. Oxacillin: intermediate resistanse $(12)-3 \%$ of isolated strains, resistant $-6 \%$, susceptibile $-91 \%$ of strains. All resistant strains. Doxycycline: $28.5 \%$ - intermediate resistanse; $28.5 \%$ - resistant and $43 \%$ susceptible strains.

There were $7.8 \%$ of the strains from which $92 \%$ were resistant to lincomycin. Clindamycin: $42 \%-$ resistant, $58 \%$ of susceptible isolates. $100 \%$ of the coagulase-positive Staphylococcus spp. were resistant to Norfloxacin and Ciprofloxacinum. 4.7\% and $95.3 \%$ of resistant strains were susceptible to Ofloxacin. Pefloxacin: 10\% - resistant, $60 \%$ - intermediate resistanse and 30\% susceptible isolates. Lomefloxacin was found to be resistant in $87 \%$ of strains, intermediate in $6.5 \%$ and susceptible in $6.5 \%$ of strains. $6.7 \%$ of the isolated strains were susceptible to Levofloxacin and the remaining 93.3\% were resistant There were 97\% cultures resistants and 3\% isolates which showed susceptibility to Sparfloxacin. Gatifloxacin: intermediate resistanse strains $-13 \%$ and $87 \%$ - resistant strains. The $84.6 \%$ demonstrated resistance to rifampicin $7.7 \%$ and intermediate resistanse $7.7 \%$ of strains.

In the group of coagulase-negative Staphylococcus spp. isolated from pigs in farm No. 1, there were $25 \%$ resistant strains and $75 \%$ strains showed susceptibility to Benzylpenicillin. All 100\% strains were susceptible to Oxacillin. Ampicillin: 13\% of strains were susceptible, $87 \%$ of strains - resistant. Gentamicin: $46 \%$ of strains were susceptible and $54 \%$ - resistant. There were $92 \%$ susceptible and $8 \%$ resistant strains to Tobramycin. Erythromycin: $6.9 \%$ of strains were resistant and $6.9 \%$-intermediate resistanse, the rest all isolated strains $(86.2 \%)$ showed susceptibility.

Tetracycline: $81.5 \%$ of strains were intermediate resistanse, $11 \%$ - resistant, and $7.5 \%$ strains were susceptible. Doxycycline: $4 \%$ of strains were intermediate resistanse, $4 \%$ - resistant, and $92 \%$ susceptible isolates. Lincomycin: $84 \%$ of the strains were susceptible and $16 \%$ were resistant. 
$3 \%$ intermediate resistanse strains to Clindamycin, the remaining $97 \%$ - susceptible. Norfloxacin: susceptible $-3 \%$ and intermediate resistanse - 3\% and $94 \%$ - resistant strains. $80 \%$ of strains were $20 \%$ susceptible to Ciprofloxacin. Ofloxacin: susceptible $-25 \%$, resistant $-75 \%$ of isolates. Pefloxacin: resistant - 50\%, intermediate resistanse $-23 \%$, susceptible $-27 \%$ of strains.

Lomefloxacin: susceptible $-16 \%$, intermediate resistanse $-8 \%$, and resistant $-76 \%$ isolates. $8 \%$ of the strains were susceptible to Levofloxacin and $92 \%$ were resistant. $64.5 \%$ of the strains showed susceptibility to Sparfloxacin and $35.5 \%$ was resistant. There were $23 \%$ intermediate resistanse and $8 \%$ resistant and $69 \%$ of strains susceptible to Gatifloxacin. Chloramphenicol: intermediate resistanse $-7 \%$ of strains from $93 \%$ of strains. Rifampicin: $66.5 \%$ were susceptible, $24 \%$ were intermediate resistanse, and $9.5 \%$ of isolates were resistanse.

Table 2. Number of studied cultures of Staphylococcus spp. isolated in the farm No.1.

\begin{tabular}{|c|c|c|c|c|c|c|c|c|}
\hline \multirow{3}{*}{ Name of antibiotic } & \multicolumn{8}{|c|}{ The number of cultures of Staphylococcus spp. } \\
\hline & \multicolumn{4}{|c|}{ Coagulase-positive } & \multicolumn{4}{|c|}{ Coagulase-negative } \\
\hline & $\mathrm{S}$ & I & $\mathrm{R}$ & Total & S & I & $\mathrm{R}$ & Total \\
\hline \multicolumn{9}{|c|}{ Penicillins } \\
\hline Benzylpenicillin & 0 & 0 & 18 & 18 & 7 & 0 & 21 & 28 \\
\hline Oxacillin & 30 & 1 & 2 & 33 & 31 & 0 & 0 & 31 \\
\hline Ampicillin & 0 & 0 & 14 & 14 & 3 & 0 & 20 & 23 \\
\hline \multicolumn{9}{|c|}{ Aminoglycosides } \\
\hline Gentamicin (I) & 13 & 0 & 1 & 14 & 12 & 0 & 14 & 26 \\
\hline Tobromycin (II) & 14 & 0 & 0 & 14 & 23 & 0 & 2 & 25 \\
\hline \multicolumn{9}{|c|}{ Macrolides } \\
\hline Erythromycin & 29 & 2 & 2 & 33 & 25 & 2 & 2 & 29 \\
\hline \multicolumn{9}{|c|}{ Tetracyclines } \\
\hline Tetracycline & 10 & 0 & 11 & 21 & 22 & 3 & 2 & 27 \\
\hline Doxycycline & 6 & 4 & 4 & 14 & 24 & 1 & 1 & 26 \\
\hline \multicolumn{9}{|c|}{ Linkosamides } \\
\hline Lincomycin & 1 & 0 & 12 & 13 & 21 & 0 & 4 & 25 \\
\hline Clindamycin & 18 & 0 & 13 & 31 & 30 & 1 & 0 & 31 \\
\hline \multicolumn{9}{|c|}{ Fluoroquinolones } \\
\hline Norfloxacin (II) & 0 & 0 & 27 & 27 & 1 & 1 & 28 & 30 \\
\hline Ciprofloxaine (II) & 0 & 0 & 15 & 15 & 5 & 0 & 20 & 25 \\
\hline Ofloxacin (II) & 1 & 0 & 20 & 21 & 7 & 0 & 21 & 28 \\
\hline Pefloxacin (II) & 3 & 6 & 1 & 10 & 7 & 6 & 13 & 26 \\
\hline Lomefloxacin (II) & 1 & 1 & 13 & 15 & 4 & 2 & 19 & 25 \\
\hline Levofloxacin (III) & 1 & 0 & 14 & 15 & 2 & 0 & 23 & 25 \\
\hline Sparfloxacin (III) & 1 & 0 & 32 & 33 & 11 & 0 & 20 & 31 \\
\hline Gatifloxacin (IV) & 0 & 2 & 13 & 15 & 6 & 2 & 18 & 26 \\
\hline \multicolumn{9}{|c|}{ Others } \\
\hline Chloramphenicol & 32 & 0 & 0 & 32 & 27 & 2 & 0 & 29 \\
\hline Rifampicin & 11 & 1 & 1 & 13 & 14 & 5 & 2 & 21 \\
\hline
\end{tabular}

\section{DISCUSSIONS}

The obtained results indicate a significant colonization of coagulase-positive and coagulase-negative staphylococci in the nasal passages of sows. A significant percentage of isolated crops possesses "pathogenicity factors". Plasma coagulation and hemolysis were particularly important. The high circulation of staphylococci in the herd leads to an increase of antibiotic resistance. Natural penicillin is known to have little effect on staphylococci, while synthetic and semisynthetic penicillin antibiotics of other groups inhibit their growth.

The results showed that in the farm No. 1 polyresistant strain of coagulase-positive and coagulase-negative staphylococci was present. A major 
component of beta-lactam resistance is the socalled mecA gene, which encodes the formation of modified penicillin-binding protein and thus interferes with the incorporation of beta-lactam into the cell wall. When the cell is methicillin-resistant Staphylococcus aureus in contact with $\beta$-lactam antibiotics, the additional $\beta$-lactam-resistant penicillin binding protein (PBP2a) takes on the biosynthetic functions of normal PBPs.

Staphylococcus aureus resistance to methicillin (Oxacillin) may be due to the production of additional PBP-2a, which is encoded by the chromosomal mecA gene, inactivation through hyper production of $\beta$-lactamases and modification of normal PBPs. The presence two resistant strains of coagulase-positive staphylococci and one intermediate resistanse in pigs may indicate the possible presence of the mecA gene. Also, the resistance of the isolated strains to Ampicillin indicates the synthesis of staphylococcal penicillinase. The higher resistance to Tetracycline was shown by coagulase-positive staphylococci, which was confirmed by the resistance of these strains to Doxycycline. Also, indicative is the resistance of some coagulase-positive staphylococci to both Lycomycin and Clindamycin, which is not observed among coagulase-negative strains. Practically all staphylococci have been shown to be resistant to Fluoroquinolones of different generations, including Gatifloxacin. Two intermediate resistanse strains of coagulase-negative staphylococci were detected for Chloramphenicol while all coagulase-positive strains were susceptible.

As a result, the circulation of polyresistant coagulase-positive staphylococcus strains proved to be resistant to almost all antibiotic groups, especially to Fluoroquinolones - $4.6 \%$ susceptible, $6.0 \%$ intermediate resistanse, and $89.4 \%$ - resistant. Among coagulase-negative staphylococci, 20\% were susceptible, $5.0 \%$ were intermediate resistanse, and $75 \%$ were resistant to Fluoroquinolines. Coagulase-negative strains from farm No. 2 also had poly resistant properties in tested antibiotics of all groups.

\section{CONCLUSIONS}

1. High percentage of staphylococcus circulation in pigs of experimental farms was detected.

2. The selected strains possessed "pathogenicity factors" by hemolysis and plasma coagulation.

3. Some staphylococci showed resistance to three or more antibiotics at the same time.

4. All these factors testify the misuse of antibiotics and the rapid manifestation of resistance to their individual representatives.

5. To confirm the emergence of the mechanism of resistance, it is necessary to carry out molecular genetic studies of isolated strains.

6. It is necessary to change fundamentally the pattern of antibiotic use in pigs in order to prevent staphylococcus resistance and their subsequent transfer to humans.

\section{CONFLICT OF INTERESTS}

All authors declare no competing interests.

\section{ACKNOWLEDGMENT}

Research was carried out with the financial support of the Ministry of Education and Science of Ukraine.

\section{REFERENCES}

1. Lowder BV, Guinane CM, Ben Zakour NL, Weinert LA, Conway-Morris A, Cartwright RA, et al. Recent human - to - poultry host jump, adaptation, and pandemic spread of Staphylococcus aureus. Proc Natl Acad Sci USA. 2009; 106(46):19545-19550.
2. Kadariya J, Smith T.C, Thapaliya D. Staphylococcus aureus and Staphylococcal Food-Borne Disease: An Ongoing Challenge in Public Health. Biomed Res Int. 2014; 2014:827965.

3. Armand-Lefevre L, Ruimy R, Andre Mont A. Clonal comparison of Staphylococcus aureus isolates from healthy pig farmers, human controls, and pigs. Emerg. infect dis. 2005; 11(5):711-714.

4. Lewis H, Molbak K, Reese C, et al. Pigs as source of methicillin-resistant Staphylococcus aureus cc398 infections in humans, Denmark. Emerg infect dis. 2008; 14(9):1383-1389.

5. Khanna T, Friendship R, Dewey C, et al. Methicillin resistant Staphylococcus aureus colonization in pigs and pig farmers. Veterinary microbiology. 2008; 128(3-4):298-303. 
6. Cuny C, Nathaus R, Layer F, et al. Nasal colonization of humans with methicillin-resistant Staphylococcus aureus (MRSA) CC398 with and without Exposure to Pigs. Plos one. 2009; 4(8):e6800.

7. Oppliger A, Moreillon P, Charrière N, et al. Antimicrobial Resistance of Staphylococcus aureus Strains Acquired by Pig Farmers from Pigs. Appl Environ Microbiol. 2012; 78(22):8010-8014.

8. Duijkeren E, Jansen MD, Flemming CS, et al. Methicillin-Resistant Staphylococcus aureus in Pigs with Exudative Epidermitis. Emerg Infect Dis. 2007; 13(9):1408-1410.

9. Fertner M, Pedersen K, Chriél M. Experimental exposure of farmed mink (Neovisonvison) to livestock-associated methicillin-resistant Staphylococcus aureus contaminated feed. Veterinary Microbiology. 2019; 231:45-47.

10. Kozytska T, Garkavenko T. Circulation of Methicillin-Resistant Staphylococcus (MRS) in Livestock and Domestic
Animals. Proceedings of the BTRP Ukraine Regional One Health Research Symposium. 2019, Kyiv.

11. Eucast. The european committee on antimicrobial susceptibility testing (2018). Available from: http:// www.eucast.org/ [Accessed 10th September 2019].

12. Ministry of health of Ukraine. Determination of susceptibility of microorganisms to antibacterial drugs (2009). Available from: https://zakon.rada.gov.ua/ rada/show/v0167282-07 [Accessed 10th September 2019].

13. Chambers H, Deleo F. Waves of resistance: Staphylococcus aureus in the antibiotic era. Nat rev microbiol. 2009; 7(9):629-641.

14. Nicola F, McDougal L, Biddle J, et al. Characterization of Erythromycin-Resistant Isolates of Staphylococcus aureus Recovered in the United States from 1958 through. Antimicrob Agents Chemother. 1998; 42(11):3024-3027.

\section{Date of receipt of the manuscript: 10/09/2019 \\ Date of acceptance for publication: 03/03/2020}

Yuriy VISHOVAN, ORCID 0000-0003-1128-593X

Valerii USHKALOV, ORCID 0000-0002-2328-1082, SCOPUS Author ID 36130483300

Oleksandra KEPPLE, ORCID 0000-0002-8123-3310, Web of Science Researcher ID B-2919-2018

Andry GRANATE, ORCID 0000-0002-5631-9139 